\title{
O "CARTESIANISMO PROCESSUAL" \\ EM TERRAE BRASILIS: A FILOSOFIA \\ E O PROCESSO EM TEMPOS DE PROTAGONISMO JUDICIAL
}

\author{
"PROCEDURAL CARTESIANISM" IN TERRAE BRASILIS: THE PHILOSOPHY AND THE PROCESS IN \\ TIMES OF LEGAL PROTAGONISM \\ EL "CARTESIANISMO PROCESAL" EN TERRAE BRASILIS: LA FILOSOFÍA Y EL PROCESO EN \\ TIEMPOS DE PROTAGONISMO JUDICIAL
}

Lenio Luiz Streck ${ }^{1}$

Rafael Tomaz de Oliveira²

André Karam Trindade ${ }^{3}$

\section{NOTAS INTRODUTÓRIAS}

No momento em que somos chamados a refletir sobre Filosofia e Processo, algumas questões, certamente, ocupam lugar privilegiado. Principalmente quando, no Brasil, estamos prestes a receber um Novo Código de Processo Civil e um Novo Código de Processo Penal, ambos já aprovados no Senado Federal e aguardando votação na Câmara dos Deputados. Há, ainda, um Projeto de Código Brasileiro de Processo Coletivo que não deve demorar muito para acompanhar os co-irmãos em seus respectivos destinos. Enfim, estamos diante de uma situação que indica uma verdadeira recomposição de todo arcabouço processual, ao menos no que tange à espinha dorsal de todo "sistema" brasileiro. Todavia essas inovações legislativas continuam acometidas de uma patologia que acompanha nosso Direito processual desde longínqua data: a ausência de uma reflexão mais profunda e demorada acerca de temas que tocam a origem - filosófica - de seus institutos. Vejamos aqui alguns casos emblemáticos: em primeiro lugar, é preciso perceber que a modernidade oferece contornos específicos ao modo como a Teoria do Direito Processual será desenvolvida. Vale dizer, por mais que exista uma origem romana em nosso modelo de direito processual, a modernidade ofereceu contornos novos e coloridos absolutamente diferentes daqueles herdados do Direito Romano. Veja-se, de plano, o que ocorre com o conceito de jurisdição, que perde qualquer nuance de atividade privada e passa a ser monopólio do Estado. Estado esse que só existe - com toda carga de complexidade e diferenciação funcional burocrática (Weber) - na modernidade. Portanto essa é uma primeira característica singular que acomete à moderna Teoria Processual: a jurisdição passa a ser monopólio do Estado. Esse fator pode parecer uma obviedade e, por isso, esconde o perigo filosófico de subestimação das obviedades: recalcar a reflexão em um conteúdo dogmático, não problematizado criticamente.

Isso fica muito evidente no momento em que se nota, por outro lado - mas conexamente ao primeiro ponto formulado -, que a emergência do Estado, suas funções e toda sua complexidade burocrática apenas foram possíveis porque a modernidade "inventou" o sujeito. Com efeito, na senda dessa "invenção", a luta por autoafirmação (Self-Assertion) desse sujeito, como bem descreve Hans

1 Pós-doutorado em Direito (Lisboa/Portugal). Doutor e Mestre em Direito do Estado (UFSC). Professor Titular dos Cursos de Mestrado e Doutorado do Programa de Pós-Graduação em Direito da UNISINOS. Procurador de Justiça (RS).

2 Doutorando em Direito Público (UNISINOS). Mestre em Direito Público (UNISINOS). Bolsista de Doutorado do CNPq. Professor do Curso de Direito da UNAERP.

3 Doutor em Teoria e Filosofia do Direito (Roma Tre/Itália). Mestre em Direito Público (UNISINOS). Coordenador de Pesquisa e Professor de Direito Constitucional da Escola de Direito da IMED. Membro Fundador e Pesquisador do Instituto de Hermenêutica Jurídica (IHJ). Produtor Executivo do Programa "Direito \& Literatura" (TV JUSTIÇA). 
Blumenberg, irá dissolver a ordem rígida e determinista presente no mundo medieval e estabelecerá uma particular atenção para o mundo "imanente", finito e totalmente contingente, que constitui seu espaço de ação4.

Esse caráter completamente novo do sujeito moderno parece ficar de fora da reflexão processual. É possível dizer, inclusive, que, de alguma forma, permanecem pouco refletidos - no âmbito de uma filosofia do/no $0^{5}$ processo - os vínculos que existem entre Sujeito, Jurisdição e Estado. Sendo ainda mais específico: ainda não se pensou, com o devido rigor, quais as implicações do conceito filosófico de sujeito no conceito processual de jurisdição ${ }^{6}$. Certamente esse vínculo possui peculiaridades que atingem profundamente o campo histórico e as projeções significativas que cada tempo histórico imprime a tais conceitos. Pensar esse vínculo e mapear essas projeções significativas são o objetivo das presentes reflexões ${ }^{7}$.

No entanto todas essas questões acarretam problemas extremamente complexos e muito abrangentes, que acabam por levar ao tema, v.g., da chamada "secularização" da ordem teológica medieval e da "legitimidade" dos conceitos da modernidade - como aparece de maneira brilhante em O Sentido na História, de Karl Löwitt, e na crítica oferecida à tese central de Löwitt em A Legitimidade da Modernidade, de Hans Blumenberg - ou, ainda, ao problema do conceito de tempo histórico, analisado por Reinhart Koselleck ${ }^{8}$.

No caso específico da obra de Koselleck, encontramos um importante instrumento de análise para colocação de temas histórico-filosóficos no direito. Para Koselleck, pensar os tempos históricos

4 Cf. BLUMENBERG, Hans. The Legitimacy of the Modern Age. Trad. de Robert M. Wallace. Massachusetts: MIT Press, 1985, em especial p. 138. Nas palavras do autor, essa autoafirmação significa: "um programa existencial segundo o qual o homem posiciona sua existência em uma situação histórica e indica para si mesmo como lidar com a realidade que o circunda e qual uso ele fará das possibilidades que lhes são abertas" (tradução livre). No original: [Self-Assertion] It means an existential program, according to which man posits his existence in a historical situation and indicates to himself how he is going to deal with the reality surrounding him and what use he will make of the possibilities that are open to him.

5 Sobre a questão da filosofia do/no direito, ver STRECK, Lenio Luiz. Verdade e Consenso. 4. ed. São Paulo: Saraiva, 2011. Trata-se da proposta de ultrapassar uma reflexão de cunho meramente descritivo e abstrato em direção à possibilidade - e à necessidade - de uma investigação profunda e filosoficamente crítica nas questões jurídicas concretas, que envolvem algo que podemos nominar faticidade jurídica.

6 Por certo, há inúmeras contribuições no sentido de mostrar quais as implicações dos conceitos modernos de ciência e certeza - ambos atrelados às matemáticas - no modo como o processo articula o conceito de jurisdição. Nesse sentido, é preciso sempre mencionar a obra de Ovídio A. Baptista da Silva que apresenta as consequências desse modelo de pensamento - que Ovídio chama, inspirado em Thomas Kuhn, de paradigma racionalista - para a teoria processual. Essas questões aparecem, principalmente, nos livros Jurisdição e execução: na tradição jurídica romano-canônica. 3. ed. São Paulo: Forense, 2007; e Processo e ideologia: o paradigma racionalista. Rio de Janeiro: Forense, 2004. Sem desconsiderar a importância dessas contribuições, falta, ainda, pensar as repercussões que o conceito de sujeito causa no âmbito da teoria processual. Sendo mais claro: é preciso considerar as implicações que a idéia de sujeito oferece ao conceito de vontade, por exemplo, que sempre se encontra às voltas com o conceito de jurisdição (para demonstrar isso, basta mencionar a vetusta serôdia no que tange à "natureza" do provimento jurisdicional se é este uma simples declaração da vontade expressa pelo legislador - como aparece em autores como Chiovenda - ou se é um ato de vontade do próprio órgão que a prolata, como acontece na Teoria Pura do Direito, de Kelsen). É preciso, portanto, atentar para o problema do protagonismo judicial e colocar o processo numa construção teórica que se situe fora do paradigma da subjetividade. Há, nesse sentido, importantes contribuições, dentre as quais podemos citar: MOTTA, Francisco J. Borges. Levando o direito a sério: uma crítica hermenêutica ao protagonismo judicial. Florianópolis: Conceito Editorial, 2010; LEAL, André Cordeiro. Instrumentalidade do processo em crise. Belo Horizonte: Mandamentos, 2008. HOMMERDING, Adalberto Narciso. Fundamentos para uma Compreensão Hermenêutica do Processo Civil. Porto Alegre: Livraria do Advogado, 2007. De todo modo, é certo que, para pensar essas questões, precisamos retroceder, inevitavelmente, ao problema do sujeito da modernidade e ao modo como esse conceito repercute em nossos dias... E como!

7 A necessidade de enfrentamento do problema do sujeito da modernidade, que, no plano da interpretação do direito acontece, de forma privilegiada, na decisão judicial, pode ser vista amiúde em STRECK, Lenio Luiz. O que é isto - decido conforme minha consciência? 2. ed. Porto Alegre: Livraria do Advogado, 2010.

8 Cf. KOSELLECK, Reinhart. Futuro Passado: Contribuição à semântica dos tempos históricos. Rio de Janeiro: Contraponto, 2006. 
significa pensar o espaço de experiência e o horizonte de expectativas que envolvem um determinado tempo histórico, demarcando, assim, suas possibilidades semânticas ${ }^{9}$.

A tese de Koselleck é que a modernidade alterou radicalmente o espaço de experiência, produzindo um tipo de história que conduzia a um único e delimitado horizonte de expectativa (trata-se do futuro pensado a partir do passado, daí porque futuro passado). Isso se dá do seguinte modo: no contexto da alta Idade Média - entre os séculos XVI e XVII -, o modo como o tempo histórico se manifestava poderia ser apresentado a partir da seguinte máxima: historie magistra vitae (a história é a mestra/ professora da vida). Ou seja, o espaço de experiência era composto de tal forma que - desde os políticos maquiavélicos, até os letrados cristãos - todos pensavam a história a partir de seu caráter pedagógico, isto é, os erros do passado devem ser evitados no futuro; e os acertos, repetidos. O horizonte de expectativas, por outro lado, permanecia relativamente aberto na medida em que esse futuro não era absolutamente determinado pelas "lições da história". Dito de outro modo, o futuro não é o "lugar" do historiador ou do filósofo da política. O futuro é o "lugar" dos profetas e da escatologia católica que, como bem aponta Blumenberg, levava ao medo da premência do juízo final. Isto significa que o presente é pensando a partir desta dupla tensão: de um lado, o passado, que condiciona a vida a partir de seu caráter pedagógico; de outro, o futuro, que se mantém obscuro pelo temor/certeza da chegada do juízo final. Ocorre que os profetas erraram, sucessivamente, suas previsões acerca do fim total. Numa época de guerras, o início de cada conflito era tido como um prelúdio do juízo final. Apesar disso, o mundo não acabava. Pelo contrário, a engenharia do Estado Absolutista conseguiu pôr fim às guerras civis religiosas. Posteriormente, o surgimento do Estado Liberal impôs limites ao poder político, assegurando as regras de livre mercado, campo extremamente propício para a fertilização da ideia de progresso. Assim, alteram-se radicalmente o espaço de experiências - que passa a ser contingente, comportando inúmeras possibilidades de ação - e o horizonte de expectativas, uma vez que o medo do juízo final cede lugar à esperança do progresso.

A questão é que a alteração semântica do significado específico do tempo histórico na modernidade não implica um afastamento total com relação à estrutura anterior. Há elementos de continuidade que permanecem. Segundo Koselleck, isso se deve ao fato de que os tempos históricos - e os conceitos que esses tempos desenvolvem - precisam ser pensados numa dupla perspectiva: uma sincrônica (atenta às peculiaridades do tempo histórico especificamente considerado) e outra diacrônica, que se apresenta como sendo as estruturas semânticas elementares que um conceito carrega consigo de um tempo para o outro. Para que essa questão possa ficar bem compreendida, o exemplo do conceito de sujeito pode, novamente, nos auxiliar. Nesse sentido, podemos seguir Gadamer quando afirma que a palavra grega correspondente a "sujeito" é hypokeimenon - que significa "o subjacente" -, tendo sida introduzida por Aristóteles para designar aquilo que, diante das diversas formas fenomênicas do ente, subjaz como uma qualidade imutável ${ }^{10}$. Depois de descrever essa origem filosófica do sujeito, o filósofo pergunta: mas será que, quando se usa a palavra sujeito, ainda se ouve esse hipokeimenon, o que subjaz como imutável diante das várias dimensões fenômenicas do ente? Por certo que a resposta é sim e não. É não porque a tradição cartesiana, pensando o sujeito como autorreflexão, o ter-consciência-de-si, alterou radicalmente a dimensão sincrônica do conceito, de modo que, depois de Descartes, o "sujeito", o subjectum está situado na outra ponta da relação cognoscitiva. Todavia é sim, porque, em sua dimensão diacrônica, o conceito de sujeito preserva um elemento semântico do conceito aristotélico de hipokeimenon, consistente na ideia de que, diante de um mundo cuja realidade foi coloca em dúvida, há algo que permanece isento de qualquer mobilidade crítica: o sujeito que diz eu penso. Assim, muito embora existam nuanças completamente distintas da noção original, o conceito de sujeito encampado pela modernidade carrega consigo o caráter substancialista do hipokeimenon aristotélico, sendo este responsável, inclusive, pelo tipo de certeza - matemática - que será produzida pela filosofia moderna.

O importante - ao menos para os limites destas reflexões - é perceber como o conceito de sujeito é o responsável direto pelo tipo de "certeza" que deve produzir o processo e, ao mesmo tempo, aquele que permite construções teóricas favoráveis ao protagonismo judicial ${ }^{11}$.

9 Sobre estas duas categorias, ver Koselleck, op. cit., pp. 305 e segs.

10 Cf. GADAMER, Hans-Georg. Verdade e método II: complementos e índices. 2. ed. Petrópolis: Vozes, 2004 , p. 103, no texto intitulado A história do conceito como filosofia.

11 Sobre o problema do protagonismo judicial - e, sobretudo, sua vertente ativista, ver as críticas formuladas, recentemente, em FERRAJOLI, Luigi; STRECK, Lenio Luiz; TRINDADE, André Karam. Garantismo, hermenêutica e (neo)constitucionalismo: um debate com Luigi Ferrajoli. Porto Alegre: Livraria 


\section{O QUE ESCAPOU A DESCARTES - OS VÍNCULOS ENTRE CONCEITO DE SUJEITO E JURISDIÇÃO}

Descartes foi, sem dúvida nenhuma, o fundador da modernidade. Com ele, a ordem medieval começa a ser questionada e, no lugar da imobilidade social do medievo e da submissão do indivíduo às imposições da divindade, aparece o sujeito, a reivindicar autonomia e autoafirmação. A partir daqui, não há mais uma ordem natural a impor um determinado estilo de vida ou conduta moral; há o sujeito auto-nomos, aquele que estabelece sua própria lei. Nesse contexto, a importância de Descartes exsurge porque, com a instituição de sua Teoria do Conhecimento - lançada em seu Discurso do Método -, o filósofo desprendeu a certeza do saber das essências (que emanavam das coisas), transferindo-a para o outro polo da relação cognoscitiva - no caso, a res cogitans -, em que, sendo a certeza mais elementar de todo conhecimento, receberá o nome que, no medievo, era atribuído às coisas que estavam disponíveis e permanentes, subsistentes, subjacentes e será chamado, então, subjectum.

Filósofos como Ernst Tugendhat afirmam que a modernidade efetua apenas uma inversão do problema do conhecimento, mas, no fundo, continua a operar com muitos dos conceitos com os quais a tradição essencialista já trabalhava ${ }^{12}$. Há, no caso, apenas uma mudança de sinal: não é o intelecto que deve se adequar às coisas, mas são as coisas que devem se adequar ao intelecto.

De todo modo, é possível dizer que a pedra de toque do projeto cartesiano é dada pela ideia de certeza. Como é possível que se tenha certeza de que a realidade circundante não é uma mera ilusão de nossos sentidos? Para Descartes, a configuração dessa certeza implicava percorrer um caminho rigoroso de verificação que deveria ir da decomposição das coisas em pequenas partes, simplificando, assim, sua complexidade original, à sua posterior reconstrução, a partir de cada verificação em particular, num movimento de indução e dedução. As etapas deste percurso Descartes denominou método, que foi pelo filósofo aplicado na perspectiva de encontrar uma certeza definitiva diante da "realidade" que o circundava. Assim, além da decomposição analítica das partes do problema, o filósofo coloca o segundo ponto de sua estratégia de configuração de certezas: a dúvida. Mas como bem lembra Heidegger, Descartes não duvida por ser um cético, mas deve tornar-se alguém que duvida porque coloca o matemático como fundamento absoluto e procura, para todo o saber, uma base que Ihe corresponda. Já não se trata de encontrar uma lei fundamental para a natureza, mas, sim, o princípio mais universal e mais elevado para o Ser em geral, dirá Heidegger. $O$ eu que põe não se dirige a qualquer coisa previamente dada, mas que dá a si mesmo o que nela está. "O que nela está é eu ponho; sou aquele que põe e pensa"13.

Assim, a dúvida instala um momento de incerteza e de instabilidade, mas que, ao fim e ao cabo, permanecerá sempre acostado no eu que existe e conhece, sendo que todo conhecimento dependerá desse elemento final, fundamento absoluto de toda a realidade.

Pois, então, é preciso reconhecer que o processo lida, desde sua conformação mais detalhada no final do século XIX, com esse tipo de pressuposição no que tange à sua conformação global. Explicando melhor: há um imaginário no âmbito da teoria processual mais convencional que acredita que esse modelo cartesiano de produção de certezas deve ser reproduzido no decorrer da instrução processual.

Um exemplo bastante ilustrativo desse tipo de imaginário pode ser encontrado em José de Igreja Matos. Com efeito, depois de afirmar - como o faz, aliás, boa parte da doutrina brasileira que o objetivo maior do processo é a pacificação socia ${ }^{14}$, o autor sustenta que ela é obtida "graças

do Advogado, 2012.

12 Cf. TUGENDHAT, Ernst. Autoconciencia y Autodeterminación: una interpretación lingüístico-analítica. Madrid: Fondo de Cultura Económica, 1993, pp. 129-153.

13 Cf. HEIDEGGER, Martin. Que é uma coisa? Doutrina de Kant dos princípios transcendentais. Trad. de Carlos Morujão. Lisboa: Edições 70, 1992, p. 107.

14 Esta idéia de que o objetivo maior do processo é a pacificação social é decorrência do recrudescimento do conceito de jurisdição de Carnelutti - que ainda faz escola no interior da doutrina brasileira. Com efeito, como bem assinala Ovídio Baptista, "de acordo com a concepção largamente difundida no Brasil, a jurisdição pressupõe um conflito de interesses, qualificado pela pretensão resistida de outrem. Tal é o conceito de lide na doutrina do mestre italiano. Sem haver lide, não há atividade jurisdicional. A jurisdição é um serviço organizado pelo Estado com a finalidade de pacificar, segundo a lei, os conflitos de interesses das mais diferentes espécies" (BAPTISTA DA SILVA, Ovídio da. Curso de processo civil. 
precisamente aos rituais procedimentais que transformam a violência física numa violência simbólica, sabendo nós que o conflito pertence ao coração do processo. $O$ tempo concedido aos debates entre as partes perante os ouvidos de um terceiro imparcial e depois o tempo da reflexão do juiz convivam à aceitação social da decisão. Daí que seja questionável o imediatismo da decisão proferida logo após a discussão da causa; para a parte é importante que a decisão seja antecedida de um período de reflexão trazido pela dúvida de modo que o perdedor possa aceitar melhor o veredicto"15.

Nota-se de plano, que, para o jurista português, é o procedimento cartesiano da dúvida que assegura às partes a aceitação da sentença proferida pelo juízo, e não a explicitação da compreensão da tradição jurídica, no interior da interpretação coerente e íntegra por ele formulada.

Essa questão do paradigma da subjetividade também pode ser observada na corrente processual chamada instrumentalidade do processo ${ }^{16}$. Na verdade, foi Candido Rangel Dinamarco quem inaugurou os estudos instrumentalistas com sua tese de cátedra, cujo título estampa a denominação da doutrina. Trata-se de obra que pretende descrever a evolução da ciência do direito processual procurando atentar para tendência publicista que o processo assume no contexto do Estado Democrático de Direito, fundado com a Constituição de 1988. As teses fundamentais de tal teoria são as seguintes:

(a) Para se desvincular do sincretismo - no interior do qual não é clara a distinção entre direito material e processo - e superar o individualismo reinante nos primórdios da teoria processual, é preciso deslocar o centro gravitacional da Teoria Geral do Processo da categoria ação para a categoria jurisdição ${ }^{17}$.

(b) Com a jurisdição figurando como categoria central, a Teoria Geral do Processo necessitará explorar as condições para assegurar o contraditório e a devida participação de cada um dos interessados no processo, visto que a legitimação do sistema se dá pelo procedimento ${ }^{18}$.

(c) Sendo o processo instrumento, ele deve ser encarado como meio, e não como fim em si mesmo, de maneira que precisa ser estudado a partir de um método nitidamente teleológico. Disso decorre que a visão do processo não pode ser restrita a ele mesmo. É preciso definir escopos (fins) a partir dos quais o processo se movimenta. Desse modo, a visão instrumentalista do processo permite perceber três escopos: social, político e jurídico ${ }^{19}$.

(d) A instrumentalidade comporta um duplo sentido: um negativo; outro positivo. Em seu sentido negativo, a instrumentalidade guarda uma semelhança profunda com a instrumentalidade das formas e se refere a uma "tomada de consciência" de que o processo não é um fim em si mesmo e, portanto, as suas regras não têm valor absoluto que sobrepuje as do direito substancial e as exigências sociais de pacificação de conflitos; em seu sentido positivo, por sua vez, expressa a ideia de efetividade do processo, entendida como capacidade de exaurir os objetivos que o legitimam no contexto jurídico-social e político ${ }^{20}$.

A grande questão é que a centralidade da jurisdição e o seu encaminhamento teleológico em direção à realização dos escopos jurídico, social e político acarretam um evidente protagonismo do juiz numa verdadeira ode ao subjetivismo próprio da filosofia da consciência. Nesse sentido, temos a afirmação do próprio Dinamarco, para quem: "O juiz é o legítimo canal através de que o universo axiológico da sociedade impõe as suas pressões destinadas a definir e precisar o sentido dos textos, a suprir-lhes eventuais lacunas e a determinar a evolução do conteúdo substancial das normas constitucionais"21.

Rio de Janeiro: Forense, 2006, v. 1, p. 20).

15 MATOS, José Igreja. Um modelo de juiz para o processo civil atual. Coimbra: Coimbra Editora, 2010, p. 88.

16 Para uma crítica pormenorizada da instrumentalidade do processo, ver Tomaz de Oliveira, Rafael; ABBOUD, Georges. O dito e o não dito sobre a instrumentalidade do processo: críticas e projeções a partir de uma exploração hermenêutica da teoria processual. Revista de Processo, São Paulo, n. 166, ano 33, pp. 27/70, dez. 2008.

17 Cf. DINAMARCO, Candido Rangel. A instrumentalidade do processo. 12. ed. São Paulo: Malheiros, 2005, pp. 51-67.

18 Id., ibid., pp. 92-192.

19 Id., ibid., pp. 193-323.

20 Id., ibid., pp. 324 e segs.

21 Id., ibid., p. 47. 
Essa problemática do predomínio do paradigma da subjetividade também aparece no âmbito do processo penal no que tange ao problema dos modelos de gestão da prova e do decorrente papel do juiz em sua apreciação. Com efeito, não parece estar claro para os processualistas que o livre convencimento e a filosofia da consciência - inaugurada com o cartesianismo - são faces de uma mesma moeda. ${ }^{22}$ Ou seja, é difícil (ou impossível) entender por qual razão o livre convencimento não seria exatamente o corolário da filosofia da consciência. Tudo está indicando que os autores do projeto tentam justificar a questão de forma pragmaticista, ao dizer que é assim que os juízes pensam. Também aqui não é possível concordar. Se os juízes "pensam assim", é porque pensam a partir do paradigma ultrapassado - a filosofia da consciência - em que um sujeito "assujeita" o objeto. Trata-se, pois, de um fatalismo que não pode ser aceito no âmbito de uma teoria do direito preocupada com a democracia. Se os juristas - em especial, os juízes - efetivamente pensam assim, então temos a obrigação de dizer que estão equivocados - este, precisamente, é o papel da doutrina -, pelo menos se analisarmos o problema à luz dos paradigmas filosóficos que conformam - Ocidente a partir da superação da metafísica clássica. ${ }^{23}$

Explicando melhor isso: o paradigma da linguagem (S-S) veio exatamente para superar a figura do sujeito solipsista (criada pela modernidade). Na verdade, o livre convencimento não deixa de ser a mesma coisa que "livre apreciação da prova" ou qualquer outro nome que se dê; ele implica um sujeito atribuindo sentidos a partir de sua subjetividade assujeitadora, isto é, a partir da sua subjetividade afirmada como a certeza mais elementar que ele tem do mundo. Certeza essa que ele encontra sozinho, a partir do método. Não se resolve o problema desse solipsismo com a simples exigência de que se fundamente a decisão "já tomada no âmbito do Selbstsüchtiger". Pensar assim é dar azo a que uma decisão possa ser tomada independentemente de qualquer coisa, buscandose, a posteriori, a justificação para aquilo que já está decidido. Ora, isso é repristinar a "vontade do poder"; isso é justificar raciocínios teleológicos. Gadamer elaborou sua teoria justamente para superar o modo de pensar da hermenêutica clássica, em que, primeiro, se conhecia; depois, se interpretava, para, só então, se aplicar ${ }^{24}$.

Numa palavra: é preciso sustentar que qualquer decisão judicial possui um dever de accountability ${ }^{25}$. Com isto, não estamos simplesmente dizendo que a fundamentação "resolve" o problema decorrente do livre convencimento ou a discricionariedade. Accountability é a fundamentação da fundamentação ${ }^{26}$. Isso quer dizer que nem de longe o problema da exigência de fundamentação se resolve no nível apofântico. Um vetor de racionalidade de segundo nível lógico-argumentativo - não pode substituir o vetor de racionalidade de primeiro nível, que é a compreensão. Nela, na compreensão, reside a "razão hermenêutica", para usar a expressão de Ernst Schnädelbach. Afinal, por que razão Gadamer diria que "interpretar é explicitar o compreendido"? Não nos esqueçamos, aqui, do dilema das teorias cognitivista-teleológicas: não é possível atravessar

22 Essa crítica, originalmente, foi feita por Lenio Streck, in Novo Código de Processo penal. O problema dos sincretismos de sistemas (inquisitorial e acusatório). Revista de Informação legislativa. Brasília, ano 46, n. 183, jul/set 2009.

23 Cfe. STRECK, Lenio Luiz. O "novo" Código de Processo Penal e as ameaças do velho inquisitorialismo: nas so(m)bras da filosofia da consciência. In: Estudos em Homenagem a Jacinto Nelson de Miranda Coutinho. Rio de Janeiro, Lumen Juris, 2011 (no prelo).

24 Quanto a isso, é importante frisar - junto com Ernildo Stein - que nós não interpretamos para compreender, mas, sim, compreendemos para interpretar. Ver, para tanto, STRECK, Lenio Luiz. Jurisdição constitucional e hermenêutica. 2. ed. Rio de Janeiro: Forense, 2004, cap. V. Este é o ponto em que reside o equívoco da tese do livre convencimento "racional". Admitimos até que a adjetivação "racional" esteja correta: afinal, o paradigma da racionalidade (solipsista) parece que ainda está presente, v.g., em todo o projeto do Novo Código de Processo Penal. Mas o que nos parece mais grave é que, talvez, o livre convencimento nem sequer seja "racional"; na verdade, tudo está indicando que ele esteja ancorado na "vontade" (não esqueçamos que as teorias exegéticas do direito, sustentadas na razão, foram superadas pela vontade, no bojo da qual surgiram tanto a jurisprudência dos valores e o realismo jurídico como também a concepção kelseniana acerca da interpretação judicial).

25 Ver Streck, O que é isto..., op. cit.

26 Registre-se, aqui, que há autores preocupados com o problema da fundamentação das decisões numa perspectiva hermenêutica. Este é o caso, por exemplo, da análise que Maurício Ramires realiza a respeito da aplicação dos precedentes no direito brasileiro. A preocupação do autor é, no fundo, com a garantia de uma fundamentação que atenta para uma conformação hermenêutica, na mesma linha do que propomos no presente artigo (cf. RAMIRES, Maurício. Crítica à aplicação de precedentes no direito brasileiro. Porto Alegre: Livraria do Advogado, 2010). 
o abismo do conhecimento - que "separa" o homem das coisas - construindo uma ponte pela qual ele já passou. Parece que os projetos do CPP e do CPC apostam nessa aporia: admitem que o juiz primeiro decide e depois fundamenta, contentando-se com um "resto de significação", ou seja, com uma capa de sentido para "justificar" a decisão solipsista "já tomada" (sic). Em síntese: o universo processual, ao contentar-se com o Livre Convencimento, acaba por fazer uma leitura superficial do art. 93, inc. IX, da CF. Pode-se até dizer que "isso é assim mesmo": os juízes primeiro decidem e depois fundamentam...!27 Isso, entretanto, não quer dizer que essa "equação cognitiva" esteja correta. Estará certa se pensarmos o direito a partir da filosofia da consciência; mas se quisermos, efetivamente, ingressar no paradigma da intersubjetividade e superar o império do sujeito solipsista, teremos que dar um passo adiante. Esse passo adiante implica admitir que a compreensão exige uma suspensão de pré-juízos e que uma decisão não pode ser produto da "vontade". Explicando melhor: o problema do livre convencimento não se esgota numa tentativa de colocar o epíteto de racional em algo que é, evidentemente, produto da vontade solipsista de um sujeito que assujeita um objeto. Pensar na possibilidade de um livre convencimento racional seria, no fundo, aceitar que o objetivo da instrução seria gerar "certeza" no julgador, com relação a uma decisão que ele já traz consigo, no íntimo de sua subjetividade - algo que, poderíamos dizer, escapa a Descartes. Ora, não se produz prova para, a partir de uma pesquisa da tradição jurídica, afirmar o "acerto" ou o "erro" da decisão, mas, sim, para compreender - corretamente - aquilo que a tradição produziu como direito e, com isso, oferecer uma interpretação coerente para o conjunto de provas que são apresentadas pelas partes. Ou seja, o juiz não deve "explicar" aquilo que o "convenceu". Deve, sim, explicitar os motivos de sua compreensão, oferecendo uma justificação (fundamentação) de sua interpretação, na perspectiva de demonstrar como a interpretação oferecida por ele é a melhor para aquele caso (mais adequada à Constituição ou, em termos dworkinianos, correta). Como bem diz Dworkin: não importa o que os juízes pensam sobre o direito, mas sim o ajuste (fit) e a justificação (justification) da interpretação que eles oferecem das práticas jurídicas em relação ao Direito da comunidade política ${ }^{28}$.

\section{ALGUMAS QUESTÕES ILUSTRATIVAS DO NCPC: O PROBLEMA DA TEORIA DO DIREITO E A QUESTÃO DOS PRINCÍPIOS - MAIS ESPAÇO PARA O PARADIGMA DA SUBJETIVIDADE (E O SUJEITO SOLIPSISTA)?}

Essa questão do sujeito e do solipsismo também repercute no modo como o projeto de Novo Código de Processo Civil vem tratando o problema da decisão e da sentença. Por certo, a recente aprovação no Senado Federal alterou alguns pontos específicos da redação originalmente dada pela comissão de juristas responsável pela formulação do $\mathrm{NCPC}^{29}$. Todavia essa questão estrutural - que representa o terreno sob o qual se enraíza nosso modelo processual - permanece recrudescida, mesmo com as alterações realizadas. É verdade que, em alguns casos, a relatoria - que é um órgão político, e não técnico - operou de forma mais científica e rigorosa do que a comissão - constituída de pessoas de reconhecida familiaridade com os temas processuais. Isso pode ser notado, por exemplo, quando a redação dada pela relatoria ao antigo art. 472 (atual art. 477) retirou, acertadamente, a menção à ponderação de valores como critério determinante para a fundamentação das sentenças. Tal questão será abordada mais adiante. De plano, porém, cabe afirmar o seguinte: na altura em que se encontra a tramitação do PSL no 166/2010, ainda há a possibilidade de ser restaurada a redação original, o que demonstra a necessidade de se refletir ainda sobre os termos propostos pela comissão de juristas que entregou o projeto de NCPC ao Senado. Vejamos, então, alguns casos importantes para a questão da decisão judicial e o modo como estão tratados no texto original do Projeto e aquele que foi oferecido pela relatoria do Senado, recentemente aprovado naquela casa legislativa.

27 Cfe. Streck, O "novo" Código de Processo Penal e as ameaças do velho inquisitorialismo, op.cit.

28 Cf. Dworkin, Ronald. Levando os direitos a sério. São Paulo: Martins Fontes, 2002, em especial o capítulo intitulado Hard Cases.

29 Com sua conversão em Projeto de Lei, o NCPC passou a se chamar PSL n 166/2010, cuja relatoriageral ficou a cargo do Senador Valter Pereira (PMDB-MS). Ressalte-se, ainda, que a relatoria conta com o apoio de uma comissão técnica composta pelos juristas Athos Gusmão Carneiro, Cassio Scarpinella Bueno, Dorival Renato Pavan e Luiz Henrique Volpe Camargo. A relatoria ofereceu uma série de alterações ao texto inicial. Para efeitos desta pesquisa, traremos um comparativo das duas redações, no que tange aos artigos citados no decorrer do texto. 
Texto original do projeto de NCPC:

Art. 108. O juiz não se exime de decidir alegando lacuna ou obscuridade da lei, cabendo-lhe, no julgamento da lide, aplicar os princípios constitucionais e as normas legais; não as havendo, recorrerá à analogia, aos costumes e aos princípios gerais de direito.

Texto aprovado pelo Senado, com redação dada pela relatoria:

Art. 119. O juiz não se exime de decidir alegando lacuna ou obscuridade do ordenamento jurídico, cabendo-Ihe, no julgamento, aplicar os princípios constitucionais, as regras legais e os princípios gerais de direito, e, se for o caso, valer-se da analogia e dos costumes ${ }^{30}$.

Texto original do projeto de NCPC:

Art. 472. O juiz proferirá a sentença de mérito acolhendo ou rejeitando, no todo ou em parte, o pedido formulado pelo autor. Nos casos de sentença sem resolução de mérito, o juiz decidirá de forma concisa.

Parágrafo único. Fundamentando-se a sentença em regras que contiverem conceitos juridicamente indeterminados, cláusulas gerais ou princípios jurídicos, o juiz deve expor, analiticamente, o sentido em que as normas foram compreendidas, demonstrando as razões pelas quais, ponderando os valores em questão e à luz das peculiaridades do caso concreto, não aplicou princípios colidentes.

Texto aprovado pelo Senado, com redação dada pela relatoria:

Art. 477. O juiz proferirá a sentença de mérito acolhendo ou rejeitando, no todo ou em parte, os pedidos formulados pelas partes. Nos casos de sentença sem resolução de mérito, o juiz decidirá de forma concisa.

Parágrafo único. Fundamentando-se a sentença em regras que contiverem conceitos juridicamente indeterminados, cláusulas gerais ou princípios jurídicos, o juiz deve expor, analiticamente, 0 sentido em que as normas foram compreendidas.

Uma rápida leitura destes dois artigos (seja na redação original do texto do Projeto de NCPC, seja naquela oferecida pela relatoria do Senado) é suficiente para corroborar a afirmação de que o que melhor simboliza a aposta no sujeito-juiz-protagonista é o anteprojeto que pretende introduzir

30 Aliás, nesse sentido, cabe um aparte: mesmo se aceitássemos os postulados da hermenêutica jurídica tradicional (o que, definitivamente, não é o caso), seria necessário perguntar - em face desta alteração sugerida pela relatoria do Senado - se, em sendo aprovado, esse dispositivo revogaria o vetusto art. $4^{\circ}$ da LICC na medida em que estabelece um novo modelo de hierarquia nos critérios tradicionais de colmatação de lacunas. Isto porque o art. $4^{\circ}$ colocava a analogia como primeiro critério para solução de lacunas, secundado pelos costumes e, apenas em casos excepcionais, os "princípios gerais do direito" (sic). Já a redação atual que o PSL no 166/2010 oferece ao art. 119 confere prioridade aos "princípios constitucionais" (sic) e, até mesmo, aos "princípios gerais do direito" (sic), relegando a analogia e os costumes à condição de critérios subsidiários, aplicados somente nos casos em que os "princípios" (sic) e as "regras legais" (sic) não derem conta de apresentarem solução. Note-se que, na sistemática atual, esse problema não existe, na medida em que o art. 126 do CPC reproduz, à sua inteireza, a ordem dos critérios determinada pelo art. $4^{\circ}$ da LICC. De todo modo, é certo que, no plano de uma hermenêutica jurídica que acompanha os resultados daquilo que o século XX produziu em termos de hermenêutica filosófica, essas questões não se apresentam como problemas. Na verdade, seria o caso de se questionar se os chamados "princípios constitucionais" são mesmo critérios de "colmatação de lacunas" como quer a redação dada pela relatoria geral do Senado ao art. 119 do PSL no 166/2010. Nos termos dessa nova hermenêutica - como vem sendo trabalhada por Lenio Streck (Verdade e Consenso, $o p$. cit.) -, os princípios são, antes de critérios de colmatação de lacunas, condição de possibilidade para legitimidade das decisões judiciais, de modo que o regramento determinado pela decisão - seja ela parcial (interlocutória) ou de mérito (sentença) - só será legítimo na medida em que dele seja possível extrair um princípio que o sustente. Esse é um ponto absolutamente fundamental. A grande questão - que nem o projeto original e nem mesmo a redação oferecida pela relatoria conseguem tocar - é que não adianta oferecer apenas novos critérios de colmatação de lacunas, caso se continue a professar o mesmo tipo de modelo de pensamento que sustentava as perspectivas tradicionais da hermenêutica jurídica, quais sejam: completude do ordenamento e a capacidade cognitiva - solipsista - do intérprete que oferece cimento à lacuna encontrada. A questão, insistimos, não é substituir mecanismos, instrumentos ou critérios, mas, sim, a própria estrutura que sustenta o todo do pensamento. De uma vez por todas: é preciso saltar da subjetividade para a intersubjetividade! 
um Novo Código de Processo Civil em terrae brasilis. Ideologicamente sustentado na escola instrumentalista, entre outras coisas, reconhece em favor do juiz o poder de adequar o mecanismo às especificidades da situação, além de reforçar a transferência das decisões colegiadas para o monocratismo. Há, entretanto, questões mais graves ainda. Com efeito, no art. 108 do anteprojeto (atual art. 119, que, embora altere a redação inicial, não modifica o "solo" que sustenta o império do solipsismo, como explicado na nota $n^{\circ} 16$ ) exsurge uma instigante questão que aponta para um sintoma gravíssimo de não superação dos paradigmas novecentistas de interpretação do direito. Muito embora a exposição de motivos do anteprojeto do NCPC faça ode à Constituição de 1988 e descreva, constantemente, a necessidade de se adaptar o processo aos problemas tipicamente contemporâneos, vemos o dispositivo em epígrafe sustentar que o juiz não pode deixar de decidir alegando lacuna (sic) ou obscuridade (sic) da Lei. O texto aprovado apenas substitui, nesta parte, o termo "lei" por "ordenamento jurídico".

Esse ponto, aliás, oferece uma ótima amostra do anacronismo que acomete a processualística brasileira e, ao mesmo tempo, como a teoria do direito não faz parte das preocupações daqueles que influem diretamente na construção do discurso legislativo. O Código de 1973 e o projeto da comissão de juristas de NCPC fala(va) em lacuna ou obscuridade da lei, um problema enfrentado pela teoria do direito do século do final do XIX e do início do século XX, a partir dos movimentos que se seguiram à jurisprudência dos interesses e ao movimento do direito livre. Assim, tanto o código vigente, de 1973, quanto o anteprojeto, de 2010, estão assentados sob postulados novecentistas. A relatoria do Senado, por sua vez, "atualiza" com pelo menos 60 anos de atraso o texto ao associar a ideia de lacuna e obscuridade não à lei - isoladamente considerada -, mas ao "ordenamento jurídico". Ocorre que "ordenamento jurídico" seria um conceito contemporâneo ao Código de 1973, que optou, entretanto, por se apegar às "descobertas" novecentistas da Teoria do Direito. Com efeito, o conceito de ordenamento jurídico foi inaugurado por Kelsen e, depois, difundido nos países de línguas latinas por Norberto Bobbio, a partir de seu clássico Teoria do Ordenamento Jurídico - de confessadas inspirações kelsenianas -, cuja publicação remonta ao final da década de 50 e ao início da década de 60. Para Bobbio, a teoria do ordenamento representava uma integração da teoria da norma jurídica, cuja premissa elementar pode ser traduzida na seguinte passagem: "as normas jurídicas nunca existem sozinhas, mas sempre num contexto de normas que tem relações específicas entre si" ${ }^{\prime 31}$. Certamente, no início da segunda metade do século XX, a ideia de ordenamento representava uma grande novidade, principalmente nos termos trabalhados pelo jusfilósofo italiano. Todavia, também a partir da década de 60, com a publicação de Verdade e Método, de Gadamer e todas as discussões que dali se seguiram, tanto com a crítica da ideologia (Habermas) quanto com setores da chamada filosofia analítica da linguagem, a hermenêutica jurídica sofreu - ou deveria sofre - sensíveis transformações, principalmente no que tange ao modo como o "objeto" da interpretação nos é dado. O grande pecado da teoria do ordenamento e, portanto, do conceito de ordenamento é que ele compreende a norma jurídica como uma entidade autônoma, que existe independentemente da interpretação. Em sendo a norma não uma representação do "existente", do "imediatamente dado", mas, sim, o produto da interpretação de um texto, a harmonia, a coerência (e a integridade, diríamos, dworkinianamente) não devem ser buscadas no ordenamento, mas na própria interpretação. $E$, aqui, é que temos a grande novidade da hermenêutica: não se deve buscar a verdade das coisas nem numa realidade externa ao sujeito, nem na própria consciência, isolada de seu entorno, mas, sim, na clivagem que existe entre consciência e mundo e que a experiência da linguagem retrata de um modo privilegiado. Esse tipo de pensamento, que polariza a experiência da linguagem em detrimento de um método garantidor de uma certeza, cujo lastro é dado pela subjetividade, ainda não penetrou suficientemente nos estudos de nossa processualística.

Por mais incrível que possa parecer a maneira como o projeto de NCPC trata a questão das lacunas e do papel do juiz na sua colmatação (e que, de certo modo, é seguida pela relatoria do Senado), encontra-se diante do vetusto imperativo do non liquet, que aparece também no art. $4^{\circ}$ da LICC. Além de repristinar, desse modo, discussões acerca daquilo que podemos chamar de "senso semântico" (semantic sense) nos debates sobre a interpretação do direito - desconsiderando, assim, as conquistas da hermenêutica filosófica e da própria teoria integrativa dworkiniana -, o anteprojeto do CPC ainda faz menção à necessidade de "utilizar", na solução da demanda, os princípios constitucionais e os princípios gerais do direito (para ficar apenas nesse ponto). É espantoso vermos

31 Cf. BOBBIO, Norberto. Teoria geral do direito. Trad. de Denise Agostinetti. São Paulo: Martins Fontes, 2007, p. 173. 
colocados lado a lado os princípios constitucionais e os velhos princípios gerais do direito. É como se não tivéssemos aprendido nada nesses duzentos anos de teoria do direito. Ora, há um sério equívoco neste tipo de incorporação legislativa, visto que não há como afirmar, simultaneamente, a existência de princípios constitucionais (cujo conteúdo deôntico é fortíssimo) com os princípios gerais do direito, que nada mais são do que instrumentos matematizantes de composição das falhas do sistema ${ }^{32}$. Vale dizer, os princípios gerais do direito não possuem força deôntica, mas são acionados apenas em casos de "lacunas" ou de obscuridade da previsão legislativa (e esses dois fatores - lacuna e obscuridade - decorrem muito mais da situação hermenêutica do intérprete do que exatamente da legislação propriamente dita). São axiomas criados para resolver os problemas decorrentes das insuficiências ônticas dos textos jurídicos. Os autores do anteprojeto, dessa forma, não compreenderam que os princípios constitucionais - na senda da revolução copernicana do direito público efetuada pelo constitucionalismo do segundo pós-guerra - representam uma ruptura com relação aos velhos princípios gerais do direito. Essa ruptura implica superar a velha metodologia privativista e introduzir um novo modelo de pensamento a respeito dos princípios. Mas o espanto não termina nisso, eis que o mesmo art. 108 opõe, ainda, "princípios constitucionais" e "normas legais" (o art. 119, aprovado no Senado, fala, de forma mais técnica, em "princípios constitucionais" e "regras legais"; no entanto a crítica aqui tecida ao texto original serve também à nova redação) ${ }^{33}$. Cabe indagar: o que são normas? E o que são normas legais? Elas se confundem com as leis ou com o texto das leis? E os princípios constitucionais? Não possuem caráter normativo?

Não fosse isso suficiente, tem-se o art. 472, segundo o qual - na mesma linha daquilo que estabelece a instrumentalidade do processo e do candente reforço do protagonismo judicial que se propõe - o juiz, na fundamentação da sentença, deverá proceder à ponderação dos princípios colidentes à luz do caso concreto, numa alusão quase explicita à teoria da argumentação jurídica proposta por Robert Alexy ${ }^{34}$. Esse particular demonstra, mais uma vez, como vivemos em meio a um peculiar anacronismo teórico, na medida em que essa ponderação de valores reivindicada pela redação do antigo art. 472 foi inventada, ainda no século XIX, pelo pai da Jurisprudência dos Interesses, Philip Heck, que apontava para a necessidade de se realizar uma ponderação (Abwägung) dos interesses sociais que tencionavam a feitura da norma. Isto porque, nos termos sugeridos por Heck, o legislador é submetido às pressões de vários grupos interessados no regramento de determinada matéria, do que se conclui que toda norma é a tentativa de "ponderar" esses interesses de forma a responder de uma maneira equilibrada ao conflito ${ }^{35}$. O que se fez em propostas mais recentes relativas à ponderação de valores que sustentam a normatividade foi simplesmente dar seguimento a essa perspectiva teórica "inventada" ainda no século XIX. No limite, a obra de Robert Alexy também se alinha a essa continuidade. De todo modo, é preciso fazer justiça a Alexy - uma vez que os autores passaram longe até mesmo de suas proposições teóricas -, na medida em que a função dos princípios, para esse autor, não se resume à colmatação de lacunas. Ora, como se sabe, Alexy reconhece um caráter normativo (deôntico) nos princípios constitucionais (sem embargo dos problemas que tal concepção pode gerar), fator que o projeto evidentemente desconsidera. Ademais, também no art. 472, é possível perceber como a processualística brasileira ainda não conseguiu ir além dos problemas metodológicos que foram instituídos no final do século XIX e no

32 Sob este ponto em específico, ver Tomaz de Oliveira, Rafael. Decisão judicial e o conceito de princípio: a hermenêutica e a (in)determinação do direito. Porto Alegre: Livraria do Advogado, 2008.

33 Os textos de ambas as redações do dispositivo em exame opõem "princípios constitucionais" e "princípios gerais do direito". A pergunta que deve ser respondida aqui é: afinal, na era dos chamados "princípios constitucionais", ainda há espaço para os vetustos "princípios gerais do direito"? Se houver, com que motivação histórica isso pode ser sustentado? De nossa parte, entendemos que os princípios constitucionais instauram uma fase da teoria do direito que instituí um novo modelo de pensamento que rompe com a tradição matematizante e privativista dos "princípios gerais do direito". Assim, em Verdade e Consenso essa questão é explicada a partir da tese da descontinuidade que, entendemos, é a maneira correta de encaminhar o pensamento sobre o conceito de princípio nessa quadra da história (cf. STRECK, Verdade e consenso..., op. cit., em especial o posfácio).

34 É certo que, como já referido no texto, a menção à ponderação de valores foi retirada na redação dada ao atual art. 477 do NCPC. Todavia a necessidade da reflexão encaminhada no texto permanece, seja porque pode voltar a figurar no dispositivo quando passar pela Câmara dos Deputados, seja porque é obra de uma comissão de juristas influentes e que, de uma ou de outra maneira, certamente formam opinião sobre essas questões.

35 Cf. LOSANO, Mario. Sistema e estrutura no direito. Trad. de Luca Lamberti. São Paulo: Martins Fontes, 2010, v. 2, p. 166. 
início do século XX, mesmo em tempos de força normativa da constituição e todas as consequências paradigmáticas que daí se seguem.

Consciente ou inconscientemente, negue ou não, a comissão de juristas, autores do projeto, o NCPC propõe um retorno (se quisermos, um retrocesso) ao positivismo semântico-normativo de cariz kelseniano. Deixar tudo para os juízes? Ora, isso Kelsen já havia deixado como herança maldita para os juristas. ${ }^{36} \mathrm{E}$ as consequências disso todos conhecemos. Hoje, nos queixamos das súmulas vinculantes...! Primeiro, incentivamos atitudes ativista-protagonistas; depois, quando tudo parece incontrolável, apelamos aos enunciados metafísico-sumulares...! A pergunta que fica é: quando é que os juristas se darão conta disso tudo?

\title{
PRAGMATISMO E FRAGMENTAÇÃO. AS RESPOSTAS DO ESTABLISHMENT AOS PROBLEMAS DA PROCESSUALÍSTICA CONTEMPORÂNEA. OS CAMINHOS - TORTUOSOS - DO PROTAGONISMO JUDICIAL E DA "IDEOLOGIA DA GESTÃO"
}

Na verdade, isto tudo acontece porque o pensamento jurídico contemporâneo está assentado em duas perigosas tendências que correm juntas. Mais do que isto: é possível dizer que elas são complementares. Trata-se do pragmaticismo e de sua mais visível e nefasta consequência: a fragmentação do conhecimento jurídico. Essa particularidade não parece ser privativa do direito brasileiro. Veja-se, por exemplo, o diagnóstico de Harold Berman sobre o estado d'arte e os destinos de toda tradição jurídica ocidental:

\begin{abstract}
Os jusfilósofos sempre debateram - e provavelmente vão continuar a fazê-lo - se o Direito está baseado na razão e na moralidade ou se é meramente fruto da vontade do detentor do poder político. Não é necessário resolver esse debate para concluir que historicamente é um fato que esses sistemas são herdeiros da Tradição Jurídica Ocidental, que são baseados em certas crenças e postulados que os próprios sistemas pressupõem como validados. Hoje, tais crenças ou postulados [...] estão rapidamente desaparecendo não apenas da mente dos legisladores, juízes, advogados, professores de Direito e outros membros da comunidade jurídica. [...] mais do que isso: eles estão desaparecendo da própria autocompreensão do Direito. O Direito está se tornando mais fragmentário, mais subjetivo, ligado mais à praticidade do que à moralidade, preocupado mais com as conseqüências imediatas do que com a sua consistência ou continuidade. Assim, o terreno histórico está sendo varrido no século XX (e isso continua no século XXI - acrescentamos) e a própria tradição está ameaçada de entrar em colapso. ${ }^{37}$ (grifamos).
\end{abstract}

Com efeito, fica cada vez mais evidente o crescimento, no campo do Direito, de posturas pragmaticistas, que defendem a solução de problemas jurídicos de forma desvinculada de qualquer padrão de racionalidade (seja ele imanente ou transcendente). Para tais posturas, o importante é que o problema seja resolvido de uma maneira rápida e "eficaz", independentemente dos critérios utilizados para se chegar à sua solução. Quando muito, esses setores do pensamento jurídico admitem um critério de ordem econômica (mercado), que, no mais das vezes, atende a uma lógica de "custos e benefícios"

Na esteira deste pragmaticismo, toma forma a tendência - cada vez mais acentuada - de retratar o fenômeno jurídico de uma forma fragmentada a partir da qual o direito seria apenas um amontoado de regras técnicas (leis, decretos, medidas provisórias, portarias, decisões judiciais, etc.), articuladas por algum agente jurídico, de um modo meramente instrumental, para resolver os conflitos de interesses que emanam do tecido social.

36 Sobre tais questões, ver Streck, o que é isto..., op. cit.

37 Ver Berman, Harold. Law and Revolution. The formation of the Western legal tradition. Massachusetts: Harvard University Press, 1983, p. 39 (tradução livre), também disponível em português: Direito e Revolução. A formação da tradição jurídica ocidental. São Leopoldo: Unisinos, 2006, p. 53.

38 De certo modo, é possível dizer que, contemporaneamente, o pragmatismo pode ser identificado sob vários matizes, como a análise econômica do direito, de Richard Posner, nos Critical Legal Studies e nas diversas posturas que colocam na subjetividade do juiz o locus de tensão da legitimidade do direito (protagonismo judicial). O pragmatismo pode ser considerado como uma teoria ou postura que aposta em um constante "estado de exceção hermenêutico" para o direito; o juiz é o protagonista, que "resolverá" os casos a partir de raciocínios e argumentos finalísticos. Trata-se, pois, de uma tese anti-hermenêutica e que coloca em segundo plano a produção democrática do direito (cf. STRECK, Verdade e consenso..., op. cit., em especial o item 10.2, in fine). 
Esse tipo de manifestação do pensamento jurídico reflete-se, também, no modo como o processo civil é organizado e estudado no Brasil. Do ponto de vista organizacional, basta dizer que, desde a década de 90, optou-se por uma técnica de reformas parciais, que procuravam reduzir o problema da tão propalada crise processual e do sistema de justiça (morosidade, excesso de processos, etc.) a partir do ataque a pontos específicos do modelo processual estabelecido pelo Código Buzaid, de 1973. Ou seja, buscava-se, de uma maneira cirúrgica e pontual, ajustar nosso arcabouço processual àquilo que já foi chamado de "tríplice exigência" do processo contemporâneo: organização, celeridade e eficácia.

Já no que tange ao estudo do processo, basta dizer que ainda aprendemos e ensinamos processo no Brasil a partir da leitura e de comentários esclarecedores dos artigos do Código, como se ainda fôssemos um rascunho - bastante infiel, diga-se de passagem - dos glosadores medievais ${ }^{39}$. Esses, por sinal, eram muito mais sofisticados que suas versões "pós-modernas", uma vez que o Digesto seu principal objeto de estudo - não era uma obra homogênea como são os códigos modernos. Os eruditos medievais tinham que "colocar ordem" na massa de informações que compunham o texto, o que faziam a partir de uma compatibilização dos textos romanos com os postulados da filosofia grega. Posteriormente, também os métodos do nominalismo filosófico fizeram parte dos estudos jurídicos e a técnica da disputatio era utilizada para problematizar determinadas questões jurídicas apresentadas pelo Digesto. Atualmente, quando muito, procuramos nas salas de aula tratar dos institutos processuais, porém quase nunca somos capazes de levar essas lições para um contexto mais global que coloque esses institutos e as regras processuais em cenário maior, que é a nossa própria tradição jurídica.

Mesmo a reforma que se encontra em curso - que, diferentemente daquelas efetuadas até o final de 2008, pretende efetuar um ajuste global do modelo processual brasileiro, oferecendo um novo código para nossa comunidade jurídica e deixando para trás a forma parcial predominante anteriormente - sofre desse problema. Aliás, é importante lembrar que estamos passando por um período de profunda modificação da política legislativa brasileira em matéria processual. Isto porque a tendência predominante sempre foi, tanto no âmbito processual civil como no penal, a de efetuar reformas parciais. Já no biênio 2009-2010, produziu-se uma proposta de reforma global, tendo sido entregue ao Congresso tanto um anteprojeto de NCPC quanto de NCPP.

De todo modo, também neste nível de reforma faltam informações claras sobre a compreensão global do Direito e, igualmente, a indicação de uma interpretação precisa de como o sistema de justiça e o próprio processo como instituição têm sido compreendidos. E o que é mais grave: não há a explicitação, tanto por parte dos autores do anteprojeto quanto daqueles que já publicaram análises do texto entregue ao Senado, acerca daquilo que possibilita as afirmações e as regras lançadas no texto do novo código. Vale dizer: nem a exposição de motivos e nem os pronunciamentos posteriores permitem identificar uma prestação de contas em torno de questões decisivas para a formatação de um novo modelo processual.

Certamente aquilo que salta aos olhos - mesmo a partir de uma rápida análise - é que falta uma preocupação em enfrentar as questões problemáticas de modo a posicioná-las, de forma o mais coerente e harmoniosa possível no todo de nossa tradição jurídica. Afinal, não somos uma ilha, nem somos um marco zero de sentido; aquilo que somos hoje se deve ao que foi construído pelo passado e é da interpretação que fazemos do passado que criamos novos sentidos. Esse fator demonstra, de plano, como há uma forte tendência pragmaticista e fragmentária no modo como o NCPC se apresenta.

39 Ilustrativa, nesse sentido, a transcrição feita por Harold Berman de um fragmento da introdução de uma aula de um professor de direito medieval, chamado Odofredus, que, por sua vez, foi citado por Savigny (Geschichte des römanischen Rechts im Mitellalter. 2. ed. Heidelberg, 1834). Trata-se de uma explicação de seu método de abordagem do Digesto, que era o "livro sagrado" dos juristas medievais: "Em primeiro lugar,eu fornecerei sínteses de cada um dos títulos - do Digesto - antes de proceder ao texto. Depois, eu darei exemplos o mais clara e explicitamente que puder, das regras individuais (contidas no título). Em terceiro lugar, eu repetirei brevemente o texto visando corrigi-lo. Em quarto lugar, eu repetirei sinteticamente os conteúdos dos exemplos (das regras). Em quinto lugar, eu resolverei as contradições, adicionando princípios gerais comumente denominados brocardia e distinções de problemas úteis e sutis, com a sua respectiva solução, se assim me permitir a Divina Providência" (cf. BERMAN, Harold. Direito e revolução. A formação da tradição jurídica ocidental. São Leopoldo: Unisinos, 2006, p. 166). Em suma: substitua-se "Digesto" por "Código Civil" ou, até mesmo "Código de Processo Civil" e qualquer semelhança com a realidade hodierna não terá sido mera coincidência (será?!?). 
É possível dizer que o grande fio condutor sob o qual caminha o NCPC pode ser identificado naquilo que, atualmente, tem sido denominado protagonismo judicial. Grosso modo, o protagonismo judicial manifesta-se como a forte corrente do pensamento jurídico-processual (não apenas brasileiro), segundo a qual ao juiz cabe um papel incisivo e, de certa forma, preponderante tanto na condução do processo quanto no seu "gerenciamento" durante o desenrolar de suas fases. Nesse sentido, é possível apontar para o seguinte exemplo retirado do projeto de NCPC:

Texto original do projeto de NCPC:

Art. 107. O juiz dirigirá o processo conforme as disposições deste Código, incumbindo-Ihe:

$[\ldots]$

$V$ - adequar as fases e os atos processuais às especificações do conflito, de modo a conferir maior efetividade à tutela do bem jurídico, respeitando sempre o contraditório e a ampla defesa;

Texto aprovado pelo Senado, com redação dada pela relatoria:

Art. 118. O juiz dirigirá o processo conforme as disposições deste Código, incumbindo-lhe:

$[\ldots]$

$V$ - dilatar os prazos processuais e alterar a ordem de produção dos meios de prova adequando-os às necessidades do conflito, de modo a conferir maior efetividade à tutela do bem jurídico;

O mesmo se verifica no momento em que o juiz profere uma decisão (em sentido amplo). Segundo os partidários dessa tese, quando decide, o juiz goza de um amplo espaço de conformação que não mais pode ser resumido na estrita subsunção da lei ao fato, mas que, agora, precisa captar os valores sociais de modo a temporalizar - no sentido de atualizar -, pela via da jurisprudência, o sentido de justiça que deve compor o Direito (nessa perspectiva vide, por todos, a posição de Candido Rangel Dinamarco).

Ocorre que, por detrás do protagonismo judicial, esconde-se uma tendência que, de uma forma bem específica, Ihe impulsiona, oferecendo uma espécie de "legitimidade" (evidentemente uma legitimidade econômico-formal, e não democrático-material). Segundo asseveram os partidários dessa tendência, o problema do sistema de justiça e do nosso modelo processual pode ser resumido e bem compreendido como um problema de gestão. Esse problema divide-se em gestão no nível macro e gestão no nível micro. No nível macro, coloca-se o problema do funcionamento do próprio sistema de justiça, com destaque para o gerenciamento funcional dos serventuários; já no nível micro, têm-se problemas de ordem burocrático-processual e de gerenciamento de questões internas ligadas ao andamento do processo, especificamente considerado. As propostas de solução desse problema de "gestão" que acomete o Poder Judiciário chegam, no limite, a indicar um modelo empresarial privado para a gestão e a organização do sistema de justiça.

No Brasil, esta tendência mostra-se cada vez mais forte e tem crescido no seio dos problemas que envolvem nosso sistema de justiça desde, pelo menos o ano de 2005, quando a Associação dos Magistrados Brasileiros encomendou uma pesquisa a cargo da cientista política Tereza Sadek, vinculada à Fundação Getúlio Vergas (publicada pela editora desta mesma instituição, inclusive, e que se encontra disponível no site da AMB).

Recentemente, Sadek voltou a afirmar em entrevista divulgada em jornais e também na Internet que o grande problema do Judiciário e do sistema de justiça como um todo no Brasil é uma questão de gestão e não de número de quadros humanos ou de modelo processual stricto sensu. Sua pesquisa teve ampla aceitação e suas afirmações ecoaram em importantes associações de magistrados em todo país.

Mas, afinal, o que significa esta gestão?

Certamente podemos afirmar que essa questão se torna mais clara nos EUA, onde o Federal Judicial Center (instituição que assegura a formação e a investigação judiciária no nível dos Tribunais 
Federais) publicou um manual de bolso para juízes com o propósito de fazê-los compreender os fatores a serem considerados na gestão cartorária e processual ${ }^{40}$.

Trata-se de cultivar práticas daquilo que, por lá, chama-se de case management (literalmente "administração do caso", num sentido nitidamente empresarial), que pressupõe a utilização "com justiça e bom senso" ( $\mathrm{sic}$ ), de todos os instrumentos à disposição dos juízes de forma a alcançar uma solução justa, rápida e não dispendiosa do litígio ${ }^{41}$.

Tal "procedimento" envolve um modelo de gestão empresarial em detrimento de uma gestão pública (considerada fortemente burocrática e "ultrapassada") do sistema de justiça e do próprio trato do processo na sua especificidade.

Esta administração empresarial da justiça apresenta três consequências: (a) a primazia do mercado como fator de decisão; (b) a redefinição das estruturas organizativas; e (c) a existência de indicadores de performance. $\mathrm{E}$, nesse mesmo sentido, cumpre referir que caminhamos a passos largos em direção a uma leitura econômica do Judiciário. Tanto é assim que o CNJ vem adotando tais medidas, de maneira avassaladora e indiscriminada, no momento em que estabelece programas de "modernização do judiciário", como o Meta 2, que agora já temos 3, 4, 5, 6... etc.).

Aqueles que "utilizam" os serviços do Judiciário e dos demais agentes do sistema de justiça são enquadrados, nesses casos, como "consumidores" (expressão empregada por Candido Rangel Dinamarco, em seu Instrumentalidade do Processo ${ }^{42}$ ) ou clientes, criando-se, nessa esteira, mecanismos de avaliação da "qualidade" do serviço prestado (novamente, trata-se de medida adotada pelo direito brasileiro). Um "controle de qualidade" poderia parecer uma boa notícia para os incautos, mas uma análise mais detida da questão pode mostrar que essa "qualidade" é medida em termos numéricos, sendo, portanto, meramente quantitativa e, portanto, apta para verificar apenas quantas decisões foram prolatas, em que período de tempo, etc. - sem nenhuma preocupação com a qualidade das decisões. Vale dizer: sem preocupação alguma com a motivação e a fundamentação das decisões judiciais.

Desenvolve-se, assim, um pretenso modelo de qualidade total, enquanto, na verdade, os fatores de medição dessa pretensa qualidade são sempre de ordem econômica, como se o mercado fosse a instância maior em que se assenta a racionalidade. Volta-se, assim, aos séculos XVII e XVIII, quando se pretendia fazer crer, como lembra Michel Foucault no Nascimento da biopolítica, que as chamadas "leis econômicas" possuíam o mesmo status de verdade que as "leis naturais", pois, tais como essas últimas, as leis econômicas eram inexoráveis e manifestavam a plenitude da razão, vale dizer, tornavam-se naturais ${ }^{43}$.

Em relação aos gestores (juízes), o modelo do case management exige que eles tenham capacidade de liderança, mobilização e motivação dos funcionários (seria uma espécie de juiz "chefe de torcida") no âmbito da administração dos cartórios, por exemplo.

No que tange aos mecanismos de gestão processual, por sua vez, citam-se como exemplo de boa gestão: (1) o emprego de técnicas de agregação de processos; (2) o agendamento comum de decisões/despachos uniformes ou temporalmente coincidentes; (3) a definição de critérios que disciplinem e tentem controlar os tempos investidos nas diligências e nas audiências; (4) a aplicação de ferramentas eletrônicas de programação e calendarização das tarefas e dos contingentes processuais; (5) a utilização de meios audiovisuais nos procedimentos e nos atos processuais, como acontece com a videoconferência, a introdução de programas e a gestão computacional; (6)

40 Cf. SCHWARZER, William W; HIRSCH, Alan. The Elements of Case Manegement: A Pocket Guide for Judges. Disponível em: http://www.fjc.gov/public/pdf.nsf/lookup/elemen02.pdf/\$file/elemen02.pdf. Acesso em: 20.12.2010.

41 Id., ibid., mais especificamente no prefácio, em cuja citação integral lê-se o seguinte: "But there is agreement that case management, in essence, involves trial judges using the tools at their disposal with fairness and common sense (and in a way that fits their personalities and styles) in order to achieve the goal described in Rule 1." A regra no 1 à qual se referem os autores consta do Código Federal de Processo, que descreve do seguinte modo o objetivo do sistema de justiça estadunidense: "to secure the just, speedy, and inexpensive determination of every action".

42 Cf. DINAMARCO, op. cit.

43 Cf. FOUCAULT, Michel. Nascimento da biopolítica. Trad. de Eduardo Brandão. São Paulo: Martins Fontes, 2008, pp. 39 e segs. 
a manipulação das virtualidades da documentação eletrônica, com a criação de modelos decisionais ou de blocos uniformes de texto para tratamento de questões jurídicas; (7) a implementação de guidelines para despachos e sentenças de maior complexidade ou para resolução de situações standardizadas com utilização do "despacho inteligente" (que ocorre quando o magistrado condensa vários despachos em um único texto, prevendo diversas alternativas que a tramitação possa vir a sofrer, evitando assim a repetida conclusão dos autos ao juiz, de modo que o processo adquira maior fluidez com uma intervenção jurisdicional única).

Em todos estes fatore citados fica nítido como a ação pró-ativa do juiz pode significar a desconsideração à formação democrática do direito e a violação de algum direito das partes.

De todo modo, o que esse trabalho pôde nos mostrar é que o modelo de juiz encampado pelo chamado protagonismo judicial tem estreitas ligação com o paradigma da subjetividade, desaguando nessa tendência, fortemente mercadológica, conhecida como "gestão do judiciário", mas que, pelo modo como se organiza e se infiltra no contexto institucional, já podemos chamar, sem exageros, de "ideologia da gestão". Mais do que isso: é possível dizer que, enquanto predominante no NCPC, infelizmente esse será o modelo que dará sustentação à nossa ordenação processual civil, caso seja aprovado em definitivo o projeto aprovado pelo Senado e encaminhado à Câmara dos Deputados.

\section{CONSIDERAÇÕES FINAIS}

Para a libertação dos dogmatismos e das estruturas teológicas que sustentavam o imaginário medieval, a modernidade criou o sujeito que, a partir de então, passou a compor um âmbito em que o objeto do conhecimento era construído, em oposição ao modelo anterior, que encarava o objeto do conhecimento como um dado. Isto foi incontestavelmente importante, pois abriu espaço para a autoafirmação do indivíduo, que passou a contestar a ordem que the era imposta pelas estruturas eclesiásticas vigentes, conquistando autonomia e construindo uma série de garantias na marcha daquilo que Norbert Elias chamou de Processo Civilizador. Ocorre que, se o nascimento da subjetividade foi condição de possibilidade para a libertação do ser humano dessa estrutura que Ihe mantinha em "cativeiro", a radicalização desse elemento subjetivo levou a outro extremo, tão perigoso quanto a ingenuidade filosófica que acometia o que podemos chamar de "mito do dado". Trata-se do solipsismo epistemológico - do sujeito moderno - que, em sua maior expressão, acaba por levar ao relativismo e à fragmentação de todo conhecimento. No caso do conhecimento jurídico, essa questão se espalha em várias dimensões, seja na questão da teoria da interpretação jurídica ou hermenêutica jurídica tradicional - que, mesmo em tempos de giro hermenêutico-filosófico, ainda se pergunta se o telos da interpretação é "descobrir" a vontade da lei ou a vontade do legislador, seja na questão da determinação processual da jurisdição, que, ao fim e ao cabo, acaba deixando de lado o enfrentamento da sua execução concreta pelo sujeito que a exerce.

Isto tem, contudo, alguns motivos determinantes, que foram, de alguma forma, apresentados nessa investigação. É importante relembrar, aqui, os principais:

I - A moderna teoria processual desenvolveu um conceito de jurisdição que está estreitamente vinculado ao conceito de sujeito. Isso fica claro não apenas porque aquele que exerce a função jurisdicional possui consciência-de-si (sendo, portanto, sujeito), mas porque estrutura o regramento da jurisdição (processo) do mesmo modo como a filosofia da subjetividade organiza seu esquema metodológico. Há um vasto número de expressões que compõem o vocabulário processual que aponta para isso. Enunciados do tipo "o destinatário da instrução é o juiz" ou, ainda, "a instrução processual visa gerar no juiz a certeza necessária para prolatação da sentença" carregam consigo a (falsa) ideia de que a "certeza" do conhecimento se forma na mente, na consciência do julgador. Como demonstramos com relação ao próprio conceito de sujeito, esse procedimento moderno de inversão do esquema sujeito-objeto não é suficiente para a determinação de um contexto de fundamentação verdadeiramente compartilhado e carrega consigo, como agravante, a concepção aristotélica de substância.

II - Essa filosofia da subjetividade que oferece a base sobre a qual se ergue as concepções modernas de jurisdição permite que se gerem as diversas teorias que conferem ao juiz o papel de protagonista. Nesse caso, as concepções instrumentalistas são aquelas que mostram, de uma maneira mais evidente, o tipo de protagonismo judicial que esse modelo filosófico alberga. Nos termos propostos por tal teoria, a jurisdição é responsável pela realização de escopos sociais, políticos 
e jurídicos, e não se reduz, simplesmente, a uma função de declaração do direito objetivo vigente (concepção que, conforme assinalamos, não deixa de ser, igualmente, subjetivista, uma vez que, na sua raiz, se encontra também o paradigma da subjetividade). Na realização de tais escopos, o juiz assume a posição de "canal privilegiado" de "substancialização" das "normas constitucionais".

De se consignar, ainda, que essa ideologia do protagonismo - sustentada em uma filosofia da subjetividade - foi incorporada de maneira efetiva e veemente no PSL no 166/2010 (projeto de Novo Código de Processo Civil). Tal constatação pode ser observada em mecanismos de gerenciamento processual (tais quais: dilação de prazos, adequação das formalidades ao caso concreto, ficando a determinação de todas essas situações a cargo do juiz) e até mesmo em regramentos relativos às decisões que continuam mantendo-se fiéis aos modelos novecentistas de interpretação do direito que desconsideravam o papel proeminente da interpretação no momento da "revelação" normativa. Ora, é na compreensão que estão assentados os elementos compartilhados historicamente pela comunidade política e que devem ser explicitados pelo julgador no momento em que apresenta sua interpretação na fundamentação de sua decisão. O não enfrentamento dessa questão acarretará o insucesso de qualquer medida que pretenda estabelecer regras hierárquicas de colmatação de lacunas.

III - Uma consequência decisiva - e talvez mais danosa - do discurso do protagonismo judicial é aquela que vem assumindo cada vez mais espaço no cenário jurídico e pode ser nomeada como "ideologia da gestão". Com efeito, as posturas que defendem um tipo de administração empresarial - tanto para o processo quanto para a jurisdição - acabam por apostar excessivamente na figura do juiz, além de atribuir a ele uma função que não faz parte de seu quadro específico de atribuições. Ocorre que isto tem consequências gravosas na medida em que indicativos oficiais como a famigerada Meta 2, do Conselho Nacional de Justiça, acabam por assinalar uma importância maior para a "gestão" judicial do que, efetivamente, para a qualidade das decisões, entendida como a prestação jurisdicional assentada em uma correta compreensão da história institucional do direito.

Por fim, é importante expressar aqui uma resposta hermenêutica para o problema apresentado: nem a objetividade ingênua do "mito do dado" e nem o absolutismo da subjetividade da modernidade, mas, sim, a exploração de um ambiente no interior do qual se dá a clivagem entre "consciência" e "mundo". É para essa dimensão que a hermenêutica volta suas baterias. Portanto, para a hermenêutica, a questão da jurisdição começa com o enfrentamento radical do problema da interpretação. Isto porque a hermenêutica sabe que a interpretação pode estar eivada de préjuízos inautênticos, impostos de uma maneira solipsista pelo sujeito-intérprete. É preciso, portanto, conquistar as condições para que esses pré-juízos sejam debelados da interpretação. E isso só se consegue a partir da construção de um verdadeiro espaço público de discussão das fundamentações das decisões, algo que podemos nomear de "constrangimento epistemológico"44 e que encontra na doutrina seu ator privilegiado, embora, na verdade, deva estar presente em toda comunidade política. Claro que isso não é direcionado ao poder Judiciário. Também os demais poderes devem ser "constrangidos" para que a legitimidade proveniente do Estado Democrático de Direito possa ser, efetivamente, aferida. E esse é um momento privilegiado para isso, já que o Novo Código de Processo Civil a despontar no horizonte - ao que parece, brevemente - afetará toda a comunidade política, e não apenas os juristas. É preciso, portanto, estarmos atento para aquilo que se afigura, de maneira muito elegante e requintada como "o novo".

Numa palavra final: é necessário, diante de uma época em que tudo aparece com o rótulo de "novo" (novo CPP, novo CPC, novo CBPC, etc.), permanecermos vigilantes para algo que Cornelius Castoriadis chamou de ascensão da insignificância. Muitas vezes, somos levados a achar que o velho, se um pouco lapidado e com algumas reformas, possa se parecer com algo novo; ou que o novo, do modo como nos é apresentado, é algo mais imponente e importante do que já foi o velho. Entretanto tudo isso, às vezes, não passa de poeira ao vento: nem a transformação era tão importante assim, nem o novo assim tão inovador... No mais, eles são apenas a manifestação da ascensão da insignificância, ávida por criar espaços para um "comércio atacadista" das ideias, à espera de consumidores que possam aprová-las. Afinal, por que o novo sempre se apresenta com ares de bondade e o velho sempre é descrito como o locus da maldade? O velho deve(ria) resistir? Ou o novo deve(rá) prevalecer? Essas perguntas só podem ser respondidas, como nos ensina a hermenêutica, a partir de um diálogo profícuo com a tradição. E a tradição... A tradição nunca emudece!

44 Expressão cunhada por Lenio Luiz Streck ( $O$ que é isto..., op. cit.). 
BAPTISTA DA SILVA, Ovídio. Processo e ideologia: o paradigma racionalista. Rio de Janeiro: Forense, 2004.

BAPTISTA DA SILVA, Ovídio da. Curso de processo civil. Rio de Janeiro: Forense, 2006. v. 1.

BAPTISTA DA SILVA, Ovídio. Jurisdição e execução: na tradição jurídica romano-canônica. 3. ed. São Paulo: Forense, 2007.

BERMAN, Harold. Law and Revolution. The formation of the Western legal tradition. Massachusetts: Harvard University Press, 1983.

BERMAN, Harold. Direito e Revolução. A formação da tradição jurídica ocidental. São Leopoldo: Unisinos, 2006.

BLUMENBERG, Hans. The Legitimacy of the Modern Age. Trad. de Robert M. Wallace. Massachusetts: MIT Press, 1985.

BOBBIO, Norberto. Teoria geral do direito. Trad. de Denise Agostinetti. São Paulo: Martins Fontes, 2007.

DINAMARCO, Candido Rangel. A instrumentalidade do processo. 12. ed. São Paulo: Malheiros, 2005.

DWORKIN, Ronald. Levando os direitos a sério. São Paulo: Martins Fontes, 2002.

FOUCAULT, Michel. Nascimento da biopolítica. Trad. de Eduardo Brandão. São Paulo: Martins Fontes, 2008.

GADAMER, Hans-Georg. Verdade e método II: complementos e índices. 2. ed. Petrópolis: Vozes, 2004.

HEIDEGGER, Martin. Que é uma coisa? Doutrina de Kant dos princípios transcendentais. Trad. de Carlos Morujão. Lisboa: Edições 70, 1992.

KOSELLECK, Reinhart. Futuro Passado: Contribuição à semântica dos tempos históricos. Rio de Janeiro: Contraponto, 2006

FERRAJOLI, Luigi; STRECK, Lenio Luiz; TRINDADE, André Karam. Garantismo, hermenêutica e (neo) constitucionalismo: um debate com Luigi Ferrajoli. Porto Alegre: Livraria do Advogado, 2012.

LEAL, André Cordeiro. Instrumentalidade do processo em crise. Belo Horizonte: Mandamentos, 2008.

LOSANO, Mario. Sistema e estrutura no direito. Trad. de Luca Lamberti. São Paulo: Martins Fontes, 2010, v. 2, p. 166.

MATOS, José Igreja. Um modelo de juiz para o processo civil atual. Coimbra: Coimbra Editora, 2010.

MOTTA, Francisco J. Borges. Levando o direito a sério: uma crítica hermenêutica ao protagonismo judicial. Florianópolis: Conceito Editorial, 2010.

RAMIRES, Maurício. Crítica à aplicação de precedentes no direito brasileiro. Porto Alegre: Livraria do Advogado, 2010.

SCHWARZER, William W; HIRSCH, Alan. The Elements of Case Manegement: A Pocket Guide for Judges. Disponível em: http://www.fjc.gov/public/pdf.nsf/lookup/elemen02.pdf/\$file/elemen02.pdf. Acesso em: 20.12.2010.

STRECK, Lenio Luiz. Jurisdição constitucional e hermenêutica. 2. ed. Rio de Janeiro: Forense, 2004.

STRECK, Lenio Luiz. O que é isto - decido conforme minha consciência? 2. ed. Porto Alegre: Livraria do Advogado, 2010. 
STRECK, Lenio Luiz. Verdade e Consenso. 4. ed. São Paulo: Saraiva, 2011.

STRECK, Lenio Luiz. Novo Código de Processo penal. O problema dos sincretismos de sistemas (inquisitorial e acusatório). In: Revista de Informação Legislativa. Brasília, ano 46, n. 183, jul/ set 2009.

TOMAZ DE OLIVEIRA, Rafael. Decisão judicial e o conceito de princípio: a hermenêutica e a (in)determinação do direito. Porto Alegre: Livraria do Advogado, 2008.

TOMAZ DE OLIVEIRA, Rafael; ABBOUD, Georges. O dito e o não-dito sobre a instrumentalidade do processo: críticas e projeções a partir de uma exploração hermenêutica da teoria processual. Revista de Processo, São Paulo, n. 166, ano 33, pp. 27/70, dez. 2008.

TUGENDHAT, Ernst. Autoconciencia y Autodeterminación: una interpretación lingüístico-analítica. Madrid: Fondo de Cultura Económica, 1993. 